\title{
Timing and progression of the Last Interglacial derived from a high alpine stalagmite
}

\author{
Steffen Holzkämper, ${ }^{1}$ Augusto Mangini, ${ }^{1}$ Christoph Spötl, ${ }^{2}$ and Manfred Mudelsee ${ }^{3}$ \\ Received 19 November 2003; revised 5 February 2004; accepted 1 March 2004; published 2 April 2004.
}

[1] U/Th dating and oxygen isotope analysis of a stalagmite from Spannagel Cave in the Austrian Alps provides information about the timing and progression of the last interglacial climate. We determined two distinct growth intervals (warm climate) from $\sim 130.7$ thousand years $(\mathrm{ka})$ before the present to $130.0 \mathrm{ka}$ and from $\sim 125.7 \mathrm{ka}$ to $118.2 \mathrm{ka}$, the latter containing two periods of ceased stalagmite growth (colder climate) at around $123.8 \mathrm{ka}$ and $120.5 \mathrm{ka}$. High resolution $\delta^{18} \mathrm{O}$ analysis of stalagmite SPA 50 reveals a clear regular cyclic pattern with periods of 197,109 , and 21 years, which are likely to be related to the Suess, Gleissberg, and Hale cycles respectively, indicating that Eemian climate in the Alps was forced by the Sun. INDEX TERMS: 1035 Geochemistry: Geochronology; 1040 Geochemistry: Isotopic composition/chemistry; 3344 Meteorology and Atmospheric Dynamics: Paleoclimatology; 7536 Solar Physics, Astrophysics, and Astronomy: Solar activity cycle (2162). Citation: Holzkämper, S., A. Mangini, C. Spötl, and M. Mudelsee (2004), Timing and progression of the Last Interglacial derived from a high alpine stalagmite, Geophys. Res. Lett., 31, L07201, doi:10.1029/2003GL019112.

\section{Introduction}

[2] The timing and duration of the Eemian interglacial climate has been extensively discussed [e.g., Shackleton et al., 2002]. According to the Milankovitch insolation curve, Marine Isotope Stage 5 (MIS 5) does not commence before $128 \mathrm{ka}$. In contrast, both marine and terrestrial datasets define the beginning of the Last Interglacial between $135 \mathrm{ka}$ and 140 ka [Gallup et al., 2002; Henderson and Slowey, 2000; Spötl et al., 2002; Winograd et al., 1992]. The stability of the Eemian climate has been discussed controversially [Boettger et al., 2000; Frogley et al., 1999; Fronval and Jansen, 1996; Hearty and Neumann, 2001; Rioual et al., 2001]. Resolving these issues will lead to an improved theory of glacialinterglacial transitions. One major setback results from the lack of reliable absolute age determinations. Speleothems offer an important but yet underutilized source of information about the timing and progression of the Last Interglacial.

\section{Geological and Climatic Setting}

[3] An ideal situation for paleoclimatic reconstruction would entail speleothem growth itself being an indicator of

\footnotetext{
${ }^{1}$ Heidelberg Academy of Sciences, Heidelberg, Germany.

${ }^{2}$ Institute of Geology and Paleontology, University of Innsbruck, Innsbruck, Austria.

${ }^{3}$ Department of Earth Sciences, Boston University, Boston, Massachusetts, USA.
}

Copyright 2004 by the American Geophysical Union. 0094-8276/04/2003GL019112\$05.00 warm climate, as is the case in Spannagel Cave, located in the Austrian Alps, at an altitude of 2,500 $\mathrm{m}$ above sea level. At present the area above Spannagel Cave is ice-free, but was covered by the nearby Hintertux Glacier during glacials [Spötl et al., 2004]. Speleothems in Spannagel are able to grow despite the absence of soil overlying the cave owing to the presence of pyrite in the host rock, which under oxidizing conditions can transform into sulfuric acid. The acid dissolves the primary limestone, producing excess $\mathrm{CO}_{2}$, which results in the formation of supersaturated carbonate solutions and calcite precipitation. The interior cave temperature (at present +1.2 to $+2.2^{\circ} \mathrm{C}$, depending on the location within the $10 \mathrm{~km}$ cave system) shows no daily or seasonal variation and corresponds closely to the mean annual external air temperature [Spötl et al., 2004]. As speleothems can only develop above freezing point, growth of speleothems in Spannagel Cave is sensitive to temperature shifts.

\section{Methods}

[4] 22 subsamples along the growth axis of stalagmite SPA 50 were taken for U/Th age determination. U/Th measurements were performed on a thermal ionization mass spectrometer (Finnigan MAT 262 RPQ) with a double filament technique ${ }^{1}$. The detrital correction was performed using a factor of 3.8 [Wedepohl, 1995] for the mass ratio of ${ }^{232} \mathrm{Th}$ and ${ }^{238} \mathrm{U}$ in the detritus. The correction led to negligible age changes $(<0.024 \mathrm{ka})$ owing to low ${ }^{232} \mathrm{Th}$ concentration. All ages were calculated using half lives for ${ }^{230} \mathrm{Th}$ of 75,381 years, for ${ }^{234} \mathrm{U}$ of 244,600 years, and for ${ }^{238} \mathrm{U}$ of $4.4683 \times 10^{9}$ years [Cheng et al., 2000]. Age errors do not include half-life uncertainties. The reproducibility of the ${ }^{233} \mathrm{U} /{ }^{236} \mathrm{U}$ double spike is $1 \%$ and that of the ${ }^{230} \mathrm{Th}$ spike is $2 \%$. Samples for stable oxygen isotope analysis were micromilled in $150-\mu \mathrm{m}$ intervals and measured using an on-line, automated carbonate preparation system linked to a triple collector gas source mass spectrometer. Values are reported relative to Vienna Pee Dee Belemnite standard. The precision of the $\delta^{18} \mathrm{O}$ values $(1 \sigma$ standard deviation of replicate analyses) is $0.075 \%$ [Spötl and Vennemann, 2003].

\section{Speleothem Growth Periods}

[5] The previously studied flowstone SPA 52 [Spötl et al., 2002] grew during MIS 7 and MIS 5. The beginning of the Last Interglacial was dated at $135.0 \pm 1.2 \mathrm{ka}$ (all errors reported are $2 \sigma$ ), and the Eemian lasted until $116.0 \pm 1.9 \mathrm{ka}$. There are no indications of post-depositional U-leaching processes (such as deviations in $\delta^{234} \mathrm{U}$ or macroscopic pores), nor is it likely that older carbonate from MIS 7 section has

\footnotetext{
${ }^{1}$ Auxiliary material is available at $\mathrm{ftp} / / / \mathrm{ftp}$.agu.org/apend/g1/ 2003GL019112.
} 


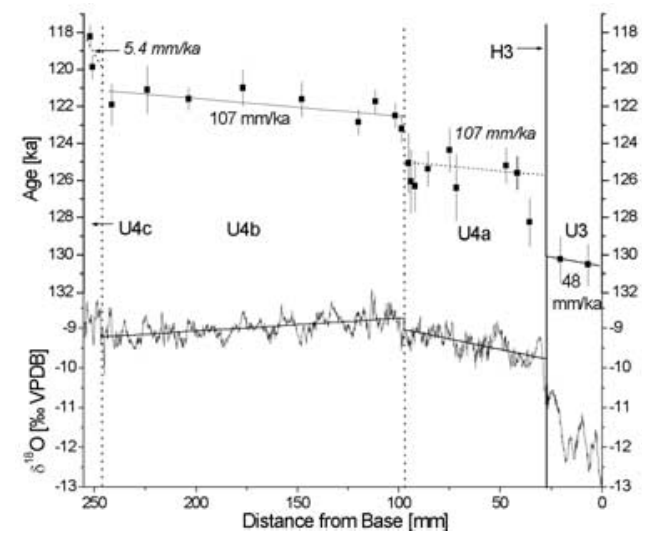

Figure 1. $\delta^{18} \mathrm{O}$ profile of stalagmite SPA 50 and U-series ages with $2 \sigma$ errors. The vertical line indicates the position of hiatus $\mathrm{H} 3$ separating growth units $\mathrm{U} 3$ and $\mathrm{U} 4$. Growth unit U4 is subdivided into three subunits, U4a, U4b, and $\mathrm{U} 4 \mathrm{c}$, by two steps in the depth age profile at about $97 \mathrm{~mm}$ and $246 \mathrm{~mm}$ from the stalagmite base (vertical dotted lines). Also shown are the calculated (solid lines) and estimated (dotted lines) age models for each growth section.

influenced the $135 \mathrm{ka}$ sample, with the respective hiatus being $11 \mathrm{~mm}$ below the spot the sample was taken from, so that the early start of the Last Interglacial is regarded as reliable. An unconformity within the MIS 5e section of the flowstone indicates a cessation of calcite deposition between $129.2 \pm 1.8$ and $121.8 \pm 0.9 \mathrm{ka}$, separating the two growth units U3 and U4. This boundary was denoted as H3 in SPA 52 [Spötl et al., 2002]. The growth intervals indicate periods with temperatures that were similar or slightly higher than today's, allowing for speleothems to form in this highaltitude cave setting. As the MIS 5e interval in SPA 52 is represented by a section of only $82 \mathrm{~mm}$ thickness, the resolution of the record is comparably poor. Here we present results from the $252 \mathrm{~mm}$ long stalagmite SPA 50, which grew in the same cave chamber only a few meters away from flowstone SPA 52 and was found lying on the cave floor detached from its substrate. Due to the higher growth rate of SPA 50 we were able to obtain a record which has a temporal resolution that is about three times higher than that of SPA 52. It is characterized by a macroscopic hiatus about $25 \mathrm{~mm}$ above its base separating the lower section with ${ }^{238} \mathrm{U}$ concentrations of about $70 \mathrm{ppm}$, denoted as $\mathrm{U} 3$, from the middle and upper sections with about 3.5 to $8.5 \mathrm{ppm}$, labeled U4 (similar concentrations were found in the respective sections of flowstone SPA 52). The lowermost $25 \mathrm{~mm}$ have a significantly higher ${ }^{232} \mathrm{Th}$ concentration of about $20 \mathrm{ppb}$ than the main section of the stalagmite (1 to $5 \mathrm{ppb}$ ), which is still too low to indicate an influence on the age determinations by detrital contamination.

[6] The first depositional phase of SPA 50 (U3) yielded ages of $130.5 \pm 1.1 \mathrm{ka}$ and $130.2 \pm 1.2 \mathrm{ka}$ (Figure 1). Thus, the growth of stalagmite SPA 50 commenced about $4.5 \mathrm{ka}$ later than that of flowstone SPA 52. Whilst stalagmite growth requires water seepage from the ceiling, the presence of water on the ground is sufficient for flowstone growth. The offset in growth initiation therefore indicates that water on the ground of this cave chamber was present prior to ceiling water seepage. The subsequent growth cessation is marked by a macroscopic hiatus and a step in the age-depth profile and may be associated with a Younger Dryas-like cold spell occurring after a first warming of the Last Interglacial. Its existence has also been recorded in other climate archives [Esat et al., 1999; Sanchez Goni et al., 1999]. It might have been caused by freshwater pulses to the North Atlantic, reducing the formation of North Atlantic Deep Water and thus the heat transport to Northern Europe [Clark et al., 2001], as in the Younger Dryas, which also occurred within a period of maximum solar summer insolation. After the growth cessation, calcite deposition recommenced at $125.6 \pm 0.9 \mathrm{ka}$ (U4). The youngest available date for this growth phase was obtained at $118.2 \pm 0.6 \mathrm{ka}$. One point with an age of $128.3 \pm$ $1.3 \mathrm{ka}$ from SPA 50 is interpreted as a mixing age due to the short distance from the hiatus and therefore was excluded from the following interpretation. U4 in stalagmite SPA 50 is represented by 19 dated points and shows two distinct jumps towards younger U/Th ages at around $123.8 \mathrm{ka}$ and $120.5 \mathrm{ka}$, subdividing U4 into three subunits U4a, U4b, and U4c. Ages obtained from the upper section of the adjacent flowstone sample SPA 52 [Spötl et al., 2002] scatter around the values within U4b and U4c of SPA 50. In SPA 52, the two respective growth reductions are not visible, probably due to the lower temporal resolution in comparison to SPA 50. However, the youngest age of the Last Interglacial is recorded more reliably by SPA 52 at $116.0 \pm 1.9 \mathrm{ka}$, because the uppermost part of stalagmite SPA 50 has a lower temporal resolution.

[7] Provided that the growth interruptions centered at around $123.8 \mathrm{ka}$ and $120.5 \mathrm{ka}$ recorded by the U/Th dates of SPA 50 are not the product of incidentally changed flowpaths of the drip waters, they are likely to represent cold spells when mean annual temperatures were at least $1^{\circ}$ to $2^{\circ} \mathrm{C}$ lower than today. The duration of the interruptions cannot be determined precisely due to the dating uncertainty, but is in the order of 1 to $2 \mathrm{ka}$. A number of climate archives from various locations also show the existence of cooler, but not glacial periods at $\sim 124 \mathrm{ka}$ [Hearty and Neumann, 2001; Wilson et al., 1998] and at 121 ka [Linsley, 1996; Stirling et al., 1998].

\section{Oxygen Isotope Record}

[8] In Figure 2 we show the growth periods and isotopic age profile of SPA 50. The age models for growth periods

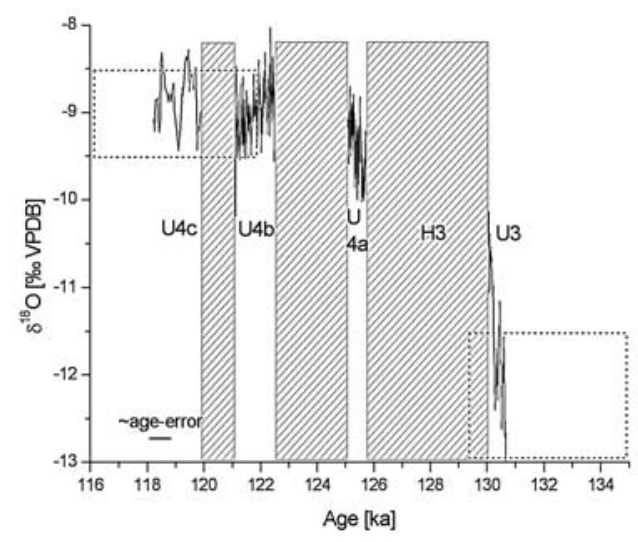

Figure 2. $\delta^{18} \mathrm{O}$ profile of stalagmite SPA 50 versus age derived from the dates shown in Figure 1. The shaded boxes mark periods of ceased stalagmite growth. The two dashed boxes indicate the growth periods and $\delta^{18} \mathrm{O}$ range of flowstone SPA 52. 
$\mathrm{U} 3$ and $\mathrm{U} 4 \mathrm{~b}$ are based on linear, error-weighted fits through the dated points, entailing growth rates of $48 \mathrm{~mm} / \mathrm{ka}$ (U3) and $107 \mathrm{~mm} / \mathrm{ka}(\mathrm{U} 4 \mathrm{~b})$, respectively. For U4a, the same growth rate as for U4b was assumed, owing to the broadly scattered ages of U4a, where a fit function would yield a negative growth rate. The growth rate of the youngest section of the stalagmite, U4c, was calculated by defining the two determined ages as the endpoints of the growth period U4c, resulting in a growth rate of $5.4 \mathrm{~mm} / \mathrm{ka}$, and not by extrapolating the growth rate to the end of the respective section, as it was performed in all the other growth phases; it therefore provides only a rough estimate.

[9] During growth phase U3 $\delta^{18} \mathrm{O}$ values in both samples range between $-13.0 \%$ and $-11.0 \%$, except for the older part of SPA 52 with fluctuations from $-10.7 \%$ to $-14 \%$. The beginning of U4 is marked by a significant increase of $\delta^{18} \mathrm{O}$ to values of around $-9.5 \%$ in both samples. It has been argued earlier that the difference of $2 \%$ to $3 \%$ in $\delta^{18} \mathrm{O}$ between sections U3 and U4 may not convincingly be explained by a temperature increase and is more likely to reflect a change in water sources [Spötl et al., 2002]. This means that the more negative isotopic values in $\mathrm{U} 3$ reflect a larger contribution of melt waters from the nearby glacier. The glacier retreat led to a stronger influence of precipitation on drip waters in the cave, leading to heavier $\delta^{18} \mathrm{O}$ values.

[10] The $\delta^{18} \mathrm{O}$ values of U4 correspond roughly with those of Holocene speleothems from Spannagel Cave, showing values around $-7.8 \%$, in equilibrium with $\delta^{18} \mathrm{O}$ of precipitation [Spötl et al., 2004]. The difference of about $1 \%$ to $2 \%$ in comparison to recent calcite would result in temperatures $4^{\circ}$ to $8^{\circ} \mathrm{C}$ higher than today [Friedman et al., 1977]. However, this difference may not solely be explained by temperature. Instead it may be ascribed to more negative $\delta^{18} \mathrm{O}$ values of precipitation or to a larger contribution of melt waters from the nearby glacier in comparison to the Holocene.

[11] During the Eemian, the profile of $\delta^{18} \mathrm{O}$ in U4a of SPA 50 increased from $-9.7 \%$ to $-9.1 \%$ and in U $4 b$ the $\delta^{18} \mathrm{O}$ values show a slight downward trend from $-8.8 \%$ to $-9.2 \%$. The boundary between $\mathrm{U} 4 \mathrm{~b}$ and $\mathrm{U} 4 \mathrm{c}$ is marked by a negative spike in $\delta^{18} \mathrm{O}$ down to $-10.3 \%$, which may indicate a relapse to colder conditions with an increased contribution of glacial melt water in the cave. High amplitude variations of $1 \%$ mark the uppermost part (U4c) before the growth ceased. Presuming that $\delta^{18} \mathrm{O}$ precipitation values remained constant during the Eemian, we can deduce from the $0.9 \%$ difference in $\delta^{18} \mathrm{O}$ values that variations in the range of $4{ }^{\circ} \mathrm{C}$ occurred, with higher temperatures at the beginning (U4a) of this period.

[12] The short term variations in $\delta^{18} \mathrm{O}$ of $\pm 0.5 \%$ in sections U4a, U4b, and U4c of stalagmite SPA 50 probably reflect both the fluctuations in temperature inside the cave, influencing the fractionation coefficient of calcite precipitation, as well as variations in the $\delta^{18} \mathrm{O}$ precipitation values. These may have been caused by any combination of the following factors: temperature, amount effect, changed seasonality of rainfall or alterations in storm and cloud tracks in the Central Alps. This latter effect has been investigated earlier [Florineth and Schlüchter, 2000], where it has been assumed that during colder periods the prevailing westerly circulation pattern over Central Europe was displaced by an enhanced southerly wind component from the Mediterranean. From our data it is not possible to

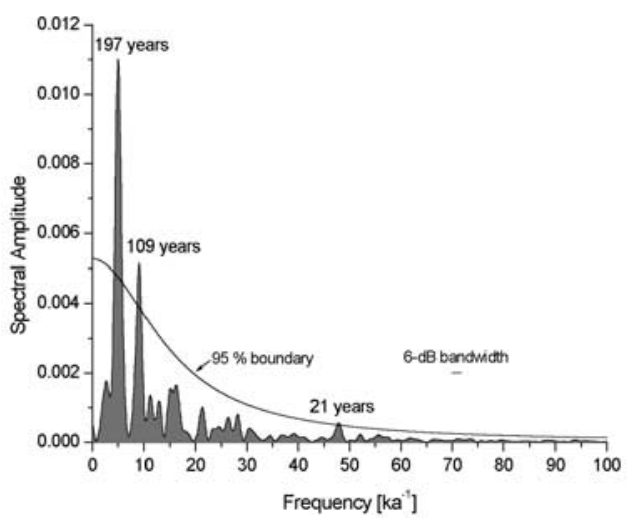

Figure 3. Spectral analysis for the high resolution interval U4b [Schulz and Mudelsee, 2002]. Spectral amplitude was estimated using the Lomb-Scargle Fourier Transform for unevenly spaced data, a Welch I window and two overlapping $(50 \%)$ segments; red-noise boundary was estimated as upper $95 \%$ chi-squared limit of a fitted AR1 process. High time-resolution and uneven spacing prohibit effectively against aliasing effects [Priestley, 1981]. The $6-\mathrm{dB}$ bandwidth (frequency resolution) is $1.77 \mathrm{ka}^{-1}$.

deduce exact temperature shifts from the stable isotope variations nor to determine the quantitative contributions of the above mentioned processes. Additional investigations, such as fluid inclusion analyses and modeling of stable isotopes in precipitation will help to quantify the relative influences of the suggested processes.

\section{Spectral Analysis}

[13] In comparison to other Eemian climate records the uniquely high resolution of the $\delta^{18} \mathrm{O}$ profile in the growth interval U4b from SPA 50 allows to decipher hidden periodicities within the time series using spectral analysis (Figure 3). Three spectral peaks at 197, 109, and 21 years period, clearly exceed the $95 \%$ confidence bound. Considering the frequency resolution (6- $\mathrm{dB}$ bandwidth) and the additional uncertainty of the used age model, these peaks might well correspond to the Suess cycle (206 years period), Gleissberg cycle (89 years), and Hale cycle (22 years), which are well established solar signals found in climate archives over Holocene periods [Hoyt and Schatten, 1997; Stuiver and Braziunas, 1993].

[14] In the Holocene, North Atlantic marine sediments reveal a strong correlation between solar induced ${ }^{10} \mathrm{Be}$ and ${ }^{14} \mathrm{C}$ fluctuations and variations in surface winds and surface ocean hydrography on centennial to millennial timescales [Bond et al., 2001]. Two Holocene stalagmites from Sauerland, Central Germany, support the finding of a teleconnection between solar activity and climate in Central Europe: the $\delta^{18} \mathrm{O}$ records of stalagmites $\mathrm{B} 7-7$ and $\mathrm{AH} 1$ show a strong correlation with the solar induced delta ${ }^{14} \mathrm{C}$ [Niggemann et al., 2002, 2003]. As the climate of Central Europe is predominantly influenced by the North Atlantic, our highresolution record SPA 50 suggests that solar activity modulated the high alpine climate during the Eemian on decadal to centennial timescales in a similar fashion. The mechanism linking solar output variations to tropospheric 
climate oscillations is still uncertain. One possibility is that variations in the intensity of galactic cosmic rays in the atmosphere cause changes in cloudiness. Another mechanism suggests that UV irradiance variations affect ozone, which changes the temperature and wind pattern in the stratosphere, in turn altering tropospheric climate [Carslaw et al., 2002; Rind, 2002].

\section{Conclusions}

[15] Our high-resolution study of speleothems from the Central Alps reveals a warm phase prior to the classical Eemian from $\sim 135$ to $130 \mathrm{ka}$. The ambient temperature during the Eemian, from $125.7 \pm 0.9$ ka to $116.0 \pm 1.9 \mathrm{ka}$, was at least as high as today in this region. This dataset provides a precise time frame for other continental climate archives for the duration of the Eemian. The growth reductions of stalagmite SPA 50 at about $123.8 \mathrm{ka}$ and $120.5 \mathrm{ka}$ could be the product of cold spells, during which the annual mean temperature was at least $1^{\circ}$ to $2^{\circ} \mathrm{C}$ lower than today. Spectral analysis reveals solar forcing of the Eemian climate.

[16] Acknowledgments. We would like to thank: G. Henderson and an anonymous reviewer for helpful comments, $M$. Wimmer for her excellent work in the stable isotope laboratory, and P. Blumbach for improvements on the manuscript's English. Funding for this study was provided by the DEKLIM program of the German Federal Ministry of Education and Research and the Austrian Science Fund (START Y122-GEO).

\section{References}

Boettger, T., F. W. Junge, and T. Litt (2000), Stable climatic conditions in central Germany during the last interglacial, J. Ouat. Sci., 15, 469-473.

Bond, G., B. Kromer, J. Beer, R. Muscheler, M. N. Evans, W. Showers, S. Hoffman, R. Lotti-Bond, I. Hajdas, and G. Bonani (2001), Persisten solar influence on North Atlantic climate during the Holocene, Science, 294, 2130-2136

Carslaw, K. S., R. G. Harrison, and J. Kirkby (2002), Cosmic rays, clouds, and climate, Science, 298, 1732-1737.

Cheng, H., R. L. Edwards, J. Hoff, C. D. Gallup, D. A. Richards, and Y. Asmeron (2000), The half-lives of ${ }^{234} \mathrm{U}$ and ${ }^{230} \mathrm{Th}$, Chem. Geol., $169,17-33$.

Clark, P. U., S. J. Marshall, G. K. C. Clarke, S. W. Hostetler, J. M. Licciardi, and J. T. Teller (2001), Freshwater forcing of abrupt climate change during the last glaciation, Science, 293, 283-287.

Esat, T. M., M. T. McCulloch, J. Chappell, B. Pillans, and A. Omura (1999), Rapid fluctuations in sea level recorded at Huon Peninsula during the penultimate deglaciation, Science, 283, 197-201.

Florineth, D., and C. Schlüchter (2000), Alpine evidence for atmospheric circulation patterns in Europe during the Last Glacial Maximum, Quat Res., 54, 295-308.

Friedman, I., J. R. O'Neil, and M. Fleischer (1977), Compilation of stable isotope fractionation factors of geochemical interest, U.S. Geol. Surv. Prof. Pap., 440-KK, 12 pp.

Frogley, M. R., P. C. Tzedakis, and T. H. E. Heaton (1999), Climate variability in northwest Greece during the last interglacial, Science, $285,1886-1889$.

Fronval, T., and E. Jansen (1996), Rapid changes in ocean circulation and heat flux in the Nordic seas during the last interglacial period, Nature, $383,806-810$

Gallup, C. D., H. Cheng, F. W. Taylor, and R. L. Edwards (2002), Direct determination of the timing of sea level change during Termination II, Science, 295, 310-313.
Hearty, P. J., and A. C. Neumann (2001), Rapid sea level and climate change at the close of the last interglaciation (MIS 5e): Evidence from the Bahama Islands, Quat. Sci. Rev., 20, 1881-1895.

Henderson, G. M., and N. C. Slowey (2000), Evidence from U-Th dating against Northern Hemisphere forcing of the penultimate deglaciation, Nature, 404, 61-66.

Hoyt, D. V., and K. H. Schatten (1997), The Role of the Sun in Climate Change, Oxford Univ. Press, New York.

Linsley, B. K. (1996), Oxygen-isotope record of sea level and climate variations in the Sulu Sea over the past 150,000 years, Nature, 380, $234-237$

Niggemann, S., A. Mangini, D. K. Richter, and G. Wurth (2002), A paleoclimate record of the last 17,600 years in stalagmites from the B7-cave, Sauerland, Germany, Quat. Sci. Rev., 22, 555-567.

Niggemann, S., A. Mangini, M. Mudelsee, D. K. Richter, and G. Wurth (2003), Sub-Milankovitch climatic cycles in Holocene stalagmites from Sauerland, Germany, Earth Planet. Sci. Lett., 216, 539-547.

Priestley, M. B. (1981), Spectral Analysis and Time Series, Academic Press, London.

Rind, D. (2002), The Sun's role in climate variations, Science, 296, 673677

Rioual, P., V. Andrieu-Ponel, M. Rietti-Shati, R. W. Battarbee, J.-L. de Beaulieu, R. Cheddadi, M. Reille, H. Svobodova, and A. Shemesh (2001), High-resolution record of climate stability in France during the last interglacial period, Nature, 413, 293-296.

Sanchez Goni, M. F., F. Eynaud, J. L. Turon, and N. J. Shackleton (1999), High resolution palynological record off the Iberian margin: Direct landsea correlation for the last interglacial complex, Earth Planet. Sci. Lett., $171,123-137$.

Schulz, M., and M. Mudelsee (2002), REDFIT: Estimating red-noise spectra directly from unevenly spaced paleoclimatic time series, Comput. Geosci., 28, 421-426.

Shackleton, N. J., M. Chapman, M. F. Sanchez-Goni, D. Pailler, and Y. Lancelot (2002), The classic marine isotope substage 5e, Quat. Res., $58,14-16$.

Spötl, C., and T. Vennemann (2003), Continuous-flow IRMS analysis of carbonate minerals, Rapid Commun. Mass Spectrom., 17, 1004-1006.

Spötl, C., A. Mangini, S. J. Burns, N. Frank, and N. Pavuza (2004), Speleothems from the High-Alpine Spannagel Cave, Zillertal Alps (Austria), in Studies of Cave Sediments: Physical and Chemical Records of Paleoclimate, edited by I. D. Sasowsky and J. Mylroie, pp. 243-256, Kluwer, Dortrecht.

Spötl, C., A. Mangini, N. Frank, R. Eichstädter, and S. J. Burns (2002), Start of the last interglacial period at $135 \mathrm{ka}$ : Evidence from a high Alpine speleothem, Geology, 30, 815-818.

Stirling, C. H., T. M. Esat, K. Lambeck, and M. T. McCulloch (1998), Timing and duration of the last interglacial: Evidence for a restricted interval of widespread coral reef growth, Earth Planet. Sci. Lett., 160, $745-762$

Stuiver, M., and T. F. Braziunas (1993), Sun, ocean, climate and atmospheric ${ }^{14} \mathrm{CO}_{2}$ : An evaluation of causal and spectral relationships, Holocene, 3, 289-305.

Wedepohl, H. K. (1995), The composition of the continental crust, Geochim. Cosmochim. Acta, 59, 1217-1232.

Wilson, M. A., H. A. Curran, and B. White (1998), Paleontological evidence of a brief global sea-level event during the last interglacial, Lethaia, 31, 241-250.

Winograd, I. J., T. B. Coplen, J. M. Landwehr, A. C. Riggs, K. R. Ludwig, B. J. Szabo, P. T. Kolesar, and K. M. Revesz (1992), Continuous 500,000 -year climate record from vein calcite in Devils Hole, Nevada, Science, 258, 255-260.

S. Holzkämper and A. Mangini, Heidelberg Academy of Sciences, Im Neuenheimer Feld 229, D-69120 Heidelberg, Germany. (steffen. holzkaemper@iup.uni-heidelberg.de)

M. Mudelsee, Department of Earth Sciences, Boston University, 685 Commonwealth Avenue, Boston, 02215 MA, USA.

C. Spötl, Institute of Geology and Paleontology, University of Innsbruck, Innrain 52, A-6020 Innsbruck, Austria. 